\section{Pharmacodynamics of doxacurium during cardiac surgery with hypothermic cardio- pulmonary bypass}

Paul McDonagh MD FFA RCSI,

Jean-Yves Dupuis MD FRCPC, Michael Curran MD FRCPC, John Kitts MD FRCPC, J. Earl Wynands MD FRCPC
Purpose: To determine the characteristics of neuromuscular block produced by two and three times the $95 \%$ effective dose $\left(E D_{95}\right)$ of doxacurium in patients undergoing coronary artery surgery with hypothermic cardiopulmonary bypass.

Methods: In a prospective non randomized study, ten putients received doxacurium $0.05 \mathrm{mg} \cdot \mathrm{kg}^{-1}$ (Group l) and ten others received $0.075 \mathrm{mg} \cdot \mathrm{kg}^{-1}$ (Group 2) with midazolan and sufentanil. The mechanomyographic response of the adductor pollicis muscle after supramaximal train-of-four (TOF) stimulation of the ulnar nerve was recorded intraoperatively and postoperatively. Additional doxacurium (10\% of the initial dose) was administered until sternal closure whenever the first twitch $\left(T_{l}\right)$ had recovered to $25 \%$ of control.

Results: The onset time (time to maximal $T_{1}$ depression) of doxacurium was $390 \pm 148 \mathrm{sec}$ in Group 1 and $370 \pm 74 \mathrm{sec}$ in Group $2(P=0.7 \mathrm{I})$. The clinical duration of neuromuscular block (time to 25\% T, recovery) was $165 \pm 90 \mathrm{~min}$ in Group I and $258 \pm 86 \mathrm{~min}$ in Group $2(P=0.03)$. On arrival to recov-

\section{Key words}

ANAESTHESIA: cardiac;

NEUROMUSCULAR RELAXANTS: doXacurium.

From the Department of Anaesthesia, University of Ottawa Heart Institute, Ottawa Civic Hospital, 1053 Carling Avenue, Ottawa, Ontario, Canada KIY 4E9.

Address correspondence to: Dr. Jean-Yves Dupuis, Department of Anaesthesia, University of Ottawa Heart Institute, Room H-213, 1053 Carling Avenue, Ottawa, Ontario, Canada, K1Y 4E9.

Phone: 613-761-4379. Fax: 613-761-4925.

The results of this study were presented in part at the Annual Meeting of the Society of Cardiovascular Anesthesiologists held in Montréal, Québec (April 24-27, 1994) and at the Annual Mecting of the Canadian Anaesthetists' Society held in Edmonton, Alberta (June 18-21, 1994).

Supported by a research grant from Burroughs Wellcome Inc., Kirkland, Québcc.

Accepted for publication 8th September, 1995. ery room the mean $T_{1}$ was $57 \pm 23 \%$ in Group $l$ and $24 \pm$ $21 \%$ in Group $2(P=0.003)$; the mean $T_{4} / T_{1}$ ratio was $0.25 \pm$ 0.15 for five patients of Group 1 with four responses to.TOF stimulation and 0.10 for the only patient of Group 2 with four twitches

Conclusion: In contrast with findings in patients without cardiac disease, this study shows comparable onset times of doxacurium with doses of two and three times $E D_{95}$. The clinical duration of doxacurium is 60 to $100 \%$ longer than previously reported in noncardiac surgery.

Objectif: Déterminer les caractéristiques du bloc neuromusculaire induit par deux et trois fois la dose efficace à $95 \%\left(E D_{95}\right)$ de doxacurium chez des patients subissant une chirurgie coronarienne sous circulation extracorporelle hypothermique.

Méthode: Dans une étude prospective non randomisée, dix patients anesthésiés avec du sufentanil et du midazolam reçoivent $0.05 \mathrm{mg} \cdot \mathrm{kg}^{-1}$ de doxacurium (groupe l) et dix autres reçoivent $0.075 \mathrm{mg} \cdot \mathrm{kg}^{-1}$ (groupe 2). La réponse mécanomyographique de l'adducteur du pouce après stimulation supramaximale du nerf cubital en train de quatre est enregistrée durant et après la chirurgie. Des doses additionnelles de doxacurium (10\% la dose initiale) sont administrées avant la fermeture du sternum dès que la première contraction de l'adducteur du pouce $\left(T_{1}\right)$ récupère à $25 \%$ de la valeur contrôle.

Résultats: Le délai d'installation (temps nécessaire pour la suppression maximale de $\left.T_{1}\right)$ du doxacurium est $390 \pm 148 \mathrm{sec}$ dans le groupe I et $370 \pm 74 \mathrm{sec}$ dans le groupe $2(P=0,71)$. $L a$ durée clinique (temps requis pour que $T$, récupère à $25 \%$ après l'administration du relaxant musculaire) est $165 \pm 90$ min dans le groupe $l$ et $258 \pm 86$ min dans le groupe 2 ( $P=$ $0,03)$. À l'arrivée à la salle de réveil, la valeur du $T_{1}$ est $57 \pm$ $23 \%$ dans le groupe $l$ et $24 \pm 21 \%$ dans le groupe 2 ( $P=$ 0,003 ); la valeur $d u T_{4} / T$, est $0,25 \pm 0,15$ pour cing patients du groupe I ayant quatre réponses musculaires et 0,10 pour le seul patient du groupe 2 ayant 4 rëponses musculaires.

Conclusion: Contrairement aux études antérieures chez des patients sans maladie cardiaque, cette étude démontre une installation du bloc neuromusculaire comparable avec des 
doses de doxacurium de deux et trois fois $E D_{45}$. La durée clinique du doxacurium est allongée de 60 à 100\% compàrativement à sa valeur durant la chirurgie noncardiaque.

Doxacurium chloride is a potent long acting nondepolarizing muscle relaxant with a reported $95 \%$ effective dose $\left(E D_{95}\right)$ of 0.023 to $0.03 \mathrm{mg} \cdot \mathrm{kg}^{-1}$. 1.2 The onset time to maximum neuromuscular block follówing $\mathrm{ED}_{95}$ administration is approximately ten minutes. ${ }^{34}$ A reduction in onset time with a corresponding increase in the duration of action and minimal haemodynamic effects have been obtained by increasing the dose of doxacurium to $0.08 \mathrm{mg} \cdot \mathrm{kg}^{-1}$ (three times $\mathrm{ED}_{95}$ ) in patients with ASA physical status I and II. ${ }^{3-5}$ Haemodynamic stability with three times $\mathrm{ED}_{95}$ of doxacurium has been documented in cardiac surgical patients. ${ }^{6-8}$ This has encouraged the use of high doses of doxacurium in induction of anaesthesia for cardiac surgery. However the clinical duration of action of doxacurium has not been established in the setting of cardiac surgery probably because this information has little relevance in patients who are electively kept sedated and whose lungs are mechanically ventilated until the day after surgery. As with other muscle relaxants, the use of hypothermic cardiopulmonary bypass (CPB) would be expected to prolong the neuromuscular block produced by doxacurium. ${ }^{9-11}$ Currently, tracheal extubation of cardiac surgical patients within three to six hours of operation is seen as desirable at many institutions. ${ }^{12-14}$ If doxacurium is to be administered to patients whose tracheas will be extubated early, then a better knowledge of its pharmacodynamic profile in this population is necessary. The present study was designed to determine the pharmacodynamic and haemodynamic characteristics of doxacurium $0.05 \mathrm{mg} \cdot \mathrm{kg}^{-1}$ and $0.075 \mathrm{mg} \cdot \mathrm{kg}^{-1}$ used as the sole muscle relaxant with a midazolam-sufentanil anaesthetic technique in 20 patients undergoing cardiac surgery with hypothermic CPB.

\section{Methods}

With hospital ethics committee approval and written informed consent, 20 patients undergoing elective coronary artery bypass graft (CABG) surgery were entered into an open, prospective, non randomized study. This method was chosen over a random dosage schedule because the main objective of the study was not to compare dosages, but to establish a range of clinical duration of doxacurium as currently used for cardiac surgical patients in our institution. Fifty- to seventy-year-old patients with stable angina and New York Heart Association functional classes II or III were included. Exclusion criteria were rhythm other than sinus, marked obesity defined as greater than $20 \%$ of ideal weight, the use of medications interfering with neuromuscular blocking agents and dysfunction of the endocrine, neurological, neuromuscular, renal. or hepatic systems. Patients were premedicated with lorazepam 2 to $3 \mathrm{mg}$ po and morphine sulphate $0.15 \mathrm{mg} \cdot \mathrm{kg}^{-1} \mathrm{im}, 90$ to 120 $\mathrm{min}$ before anaesthesia induction. Monitoring, which started before induction of anaesthesia, included electrocardiogram leads II and $\mathrm{V}_{5}$ with automated ST segment analysis (Spacelab monitor, model 90303B; Richmond, WA, USA), pulse oximetry, radial artery pressure, pulmonary artery (PA) pressure, bladder and PA temperatures, cardiac output (CO) measured by thermodilution and mixed venous oxygen saturation $\left(\mathrm{Sv}_{2}\right)$ measured by co-oximetry (Oximetrix, Abbott Critical Care Systems, North Chicago, IL, USA).

Neuromuscular monitoring was started in the operating room and continued in the cardiac recovery room. A special arm support was built in order to keep the left arm extended $60^{\circ}$ to $70^{\circ}$ and slightly rotated anteriorly with flexion of the elbow at an angle of approximately $60^{\circ}$. A Grass stimulator S88 delivered supramaximal, square-wave impulses of $0.2 \mathrm{msec}$ duration in a train-offour (TOF) sequence ( $2 \mathrm{~Hz}$ for two seconds) via needle electrodes adjacent to the left ulnar nerve at the wrist. The evoked mechanical response of the left adductor pollicis was measured by a Gould Statham ${ }^{\circledR}$ UTC3 force displacement transducer and displayed on a polygraph. The left arm and hand were covered with a blanket to prevent heat loss with precautions taken to avoid interference with the monitoring apparatus. Nerve stimulation was started at $12 \mathrm{sec}$ intervals while the patients were sedated with midazolam. A period of five minutes was allowed for stabilization of the mechanical response before induction of anaesthesia. Following administration of the muscle relaxant and after complete suppression of the first twitch $\left(T_{1}\right)$ of the train-of-four response, nerve stimulation was repeated at one-minute intervals. Neuromuscular monitoring was interrupted at the end of surgery for patient transfer to the recovery room. The force transducer remained attached to the patient and after a period of stabilization in the recovery room, neuromuscular monitoring was restarted with the same resting tension applied on the adductor pollicis as in the operating room.

Anaesthesia was induced with sufentanil 1.5 to 2.5 $\mu \mathrm{g} \cdot \mathrm{kg}^{-1}$ and midazolam 0.03 to $0.04 \mathrm{mg} \cdot \mathrm{kg}^{-1} i v$. The first ten patients (Group 1) received doxacurium 0.05 $\mathrm{mg} \cdot \mathrm{kg}^{-1}\left(2 \times \mathrm{ED}_{95}\right)$ and the next ten (Group 2) received $0.075 \mathrm{mg} \cdot \mathrm{kg}^{-1}\left(3 \times \mathrm{ED}_{95}\right)$ as a bolus into a free flowing central venous cannula. Tracheal intubation was performed when $\mathrm{T}_{1}$ was at $10 \%$ of control. Additional doses of doxacurium equivalent to $10 \%$ of the intubat- 
ing dose were administered until sternal closure whenever $T_{1}$ had recovered to $25 \%$ of control. Mechanical ventilation was provided to maintain an end-tidal carbon dioxide tension between 4.0 and $5.0 \mathrm{kPa}$. Moderate hypothermic $\left(32^{\circ} \mathrm{C}\right)$ nonpulsatile $\mathrm{CPB}$, using crystalloid prime, membrane oxygenator, flow of $2.5 \mathrm{~L} \cdot \mathrm{min}^{-1} \cdot \mathrm{m}^{-2}$ and a mean arterial pressure (MAP) of 50 to $70 \mathrm{mmHg}$ was used. Patients were rewarmed to bladder temperature greater than $36^{\circ} \mathrm{C}$ before separation from $\mathrm{CPB}$.

The time required for $\mathrm{T}_{1}$ to decline from $100 \%$ to $0 \%$ (onset time), the time for $T_{1}$ to decline from $100 \%$ to $10 \%$ (time of intubation) and the time for $T_{1}$ to recover to $25 \%$ of the initial pre-relaxant control value (clinical duration) after administration of doxacurium were recorded in all patients from both groups. The recovery index (time for $25 \%$ to $75 \% \mathrm{~T}_{1}$ spontaneous recovery) was measured whenever possible.

Prior to induction of anaesthesia, baseline measurements of heart rate (HR), MAP, CO, central venous pressure (CVP), PA occluded pressure (PAOP) and $\mathrm{SvO}_{2}$ were measured. These data were collected again prior to and at one and ten minutes after intubation. Cardiac index (CI) and systemic vascular resistance (SVR) were calculated according to standard formulae. Left ventricular myocardial oxygen consumption $\left(\mathrm{MVO}_{2}\right)$ in $\mathrm{ml} \mathrm{O}_{2} \cdot \mathrm{min}^{-1} \cdot 100 \mathrm{~g}^{-1}$ was estimated using the pressure work index (PWI) proposed by Rooke and Feigl. ${ }^{15}$ Intubating conditions were judged by the anaesthetist as excellent if there was good visualization of the glottis, good abduction of the vocal cords and no patient movement. They were judged as good if one of those conditions was missing and as poor if at least two of those conditions were missing. Adverse events such as muscle rigidity, flushing of skin, wheals and respiratory difficulties after the initial dose of doxacurium observed by the anaesthetist were recorded. Patients were electively sedated. Their lungs were ventilated overnight and their tracheas extubated the following morning. After tracheal extubation patients were questioned regarding any discomfort or loss of sensitivity in their left upper limb in order to diagnose any complication associated with prolonged neuromuscular monitoring.

Comparisons of demographic data, onset time and clinical duration of doxacurium in each group were made with unpaired Student's t test. Two-way analysis of variance for repeated measures was used to compare haemodynamic data between groups and Dunnett's $t$ test to compare values over time within each group. $P \leq 0.05$ was considered significant.

\section{Results}

No differences in preoperative and intraoperative characteristics were found between the groups (Table I).
TABLE I Preoperative and intraoperative characteristics

\begin{tabular}{|c|c|c|}
\hline & $\begin{array}{l}\text { Group l } \\
\left(0.05 \mathrm{mg} \cdot \mathrm{kg}^{-1}\right)\end{array}$ & $\begin{array}{l}\text { Group } 2 \\
\left(0.075 \mathrm{mg} \cdot \mathrm{kg}^{-1}\right)\end{array}$ \\
\hline No. of female/male patients & $1 / 9$ & $1 / 9$ \\
\hline Age (years) & $58 \pm 7$ & $58 \pm 9$ \\
\hline Weight (kg) & $88.2 \pm 15.4$ & $88.3 \pm 16.5$ \\
\hline Body surface area $\left(\mathbf{m}^{2}\right)$ & $2.02 \pm 0.17$ & $1.92 \pm 0.21$ \\
\hline \multicolumn{3}{|l|}{ No. of patients with } \\
\hline - NYHA class 2 & 8 & 7 \\
\hline - NYHA class 3 & 2 & 3 \\
\hline \multicolumn{3}{|l|}{ No. of patients taking } \\
\hline - Beta blockers & 6 & 8 \\
\hline - Calcium entry blockers & 5 & 3 \\
\hline - Nitrates & 8 & 5 \\
\hline - ACE inhibitors & 3 & 0 \\
\hline \multicolumn{3}{|l|}{$\begin{array}{l}\text { Total intraoperative anaesthetic } \\
\text { drugs }\end{array}$} \\
\hline - Sufentanil $(\mu \mathrm{g})$ & $550 \pm 180$ & $635 \pm 319$ \\
\hline - Midazolam (mg) & $19.0 \pm 7.0$ & $25.4 \pm 14.4$ \\
\hline Initial dose of doxacurium (mg) & $4.4 \pm 0.8$ & $6.6 \pm 1.3$ \\
\hline $\begin{array}{l}\text { Additional dose of doxacurium } \\
\text { (mg) }\end{array}$ & $1.0 \pm 1.1$ & $0.7 \pm 0.7$ \\
\hline $\begin{array}{l}\text { No. of patients requiring } \\
\text { additional doxacurium }\end{array}$ & 6 & 6 \\
\hline
\end{tabular}

Values are mean \pm SD except when number of patients is indicated. NYHA $=$ New York Heart Association. ACE $=$ angiolensin converting enzyme.

Temperature changes and duration of the various perioperative periods were comparable between the groups (Table II). No patient received magnesium sulphate or antiarrhythmic drugs during the study period.

The characteristics of neuromuscular block associated with both doses of doxacurium are presented in Table III. The onset time of doxacurium and the time for $T_{1}$ to decline to $10 \%$ of control were not different between the groups. A wide range in clinical duration was observed in both groups with a longer mean duration in Group 2 $(P=0.03)$. On arrival to recovery room, the mean $\mathrm{T}_{1}$ was higher in Group $1(P=0.003)$; only five patients in Group 1 had four twitches after TOF nerve stimulation with a $T_{4} / T_{1}$ ratio of $0.25 \pm 0.15$ for five patients and only one patient of Group 2 had four twitches with a $\mathrm{T}_{4} / \mathrm{T}_{1}$ ratio of 0.10 .

The recovery index could be determined in only five patients from Group 1 and six patients from Group 2. Of those patients, only two (one in each group) did not require repeated doses of doxacurium intraoperatively. The recovery index was longer in Group 2 with a wider range of recovery time than in Group 1 (Table Il). The recovery index could not be determined in three patients of Group 1 and four of Group 2 because of shivering which interfered with baseline tension. In two other patients, the recovery index was not measured because 
TABLE II Duration of the intraoperative and postoperative periods and core temperature at the end of each period

\begin{tabular}{|c|c|c|c|c|}
\hline \multirow[b]{2}{*}{ Periods } & \multicolumn{2}{|c|}{$\begin{array}{l}\text { Group l } \\
\left(0.05 \mathrm{mg} \cdot \mathrm{kg}^{-1}\right)\end{array}$} & \multicolumn{2}{|c|}{$\begin{array}{l}\text { Group } 2 \\
\left(0.075 \mathrm{mg} \cdot \mathrm{kg}^{-1}\right)\end{array}$} \\
\hline & $\begin{array}{l}\text { Duration } \\
\text { (min) }\end{array}$ & $\begin{array}{l}\text { Temperature } \\
\left({ }^{\circ} \mathrm{C}\right)\end{array}$ & $\begin{array}{l}\text { Duration } \\
\text { (min) }\end{array}$ & $\begin{array}{l}\text { Temperature. } \\
\left({ }^{\circ} \mathrm{C}\right)\end{array}$ \\
\hline Induction of anaesthesia & - & $36.5 \pm 0.4$ & - & $36.5 \pm 0.5$ \\
\hline Pre-CPB & $91 \pm 19$ & $35.0 \pm 0.5$ & $95 \pm 30$ & $35.0 \pm 0.6$ \\
\hline CPB: hypothermic & $50 \pm 11$ & $31.7 \pm 0.6$ & $50 \pm 10$ & $32.0 \pm 1.4$ \\
\hline CPB: rewarming & $56 \pm 15$ & $36.6 \pm 0.5$ & $51 \pm 22$ & $36.3 \pm 0.8$ \\
\hline Post-CPB (intraoperative) & $40 \pm 15$ & $35.0 \pm 0.7$ & $38 \pm 15$ & $34.9 \pm 0.8$ \\
\hline Transfer to recovery room & $41 \pm 16$ & $35.1 \pm 0.5$ & $44 \pm 16$ & $35.0 \pm 0.8$ \\
\hline Recovery \# I & 60 & $35.4 \pm 0.6$ & 60 & $35.3 \pm 0.8$ \\
\hline Recovery \#2 & 60 & $35.9 \pm 0.7$ & 60 & $35.9 \pm 0.9$ \\
\hline Recovery \#3 & 60 & $36.6 \pm 0.5$ & 60 & $36.6 \pm 1.1$ \\
\hline Recovery \#4 & 60 & $37.0 \pm 0.5$ & 60 & $36.8 \pm 1.3$ \\
\hline
\end{tabular}

Values are mean $\pm \mathrm{SD}$. $\mathrm{CPB}=$ cardiopulmonary bypass. Temperature was monitored from the pulmonary artery at induction and from the bladder at the other time points. Transfer to recovery room $=$ time of transfer to recovery room and period of stabilization before restarting neuromuscular monitoring.

TABLE III Characteristics of doxacurium neuromuscular block in patients undergoing cardiac surgery with hypothermic cardiopulmonary bypass

\begin{tabular}{|c|c|c|c|}
\hline & $\begin{array}{l}\text { Group l } \\
\text { O.05 mg.kg-1 } \\
(n=10)\end{array}$ & $\begin{array}{l}\text { Group } 2 \\
0.075 \mathrm{mg} \cdot \mathrm{kg}^{-1} \\
(n=10)\end{array}$ & $P$ value \\
\hline Onset time (sec) & $\begin{array}{l}390 \pm 148 \\
(180-720)\end{array}$ & $\begin{array}{l}370 \pm 74 \\
(240-480)\end{array}$ & 0.71 \\
\hline $\begin{array}{l}\text { Tine for } T_{1} \text { to decline to } \\
10 \% \text { of control }(\mathrm{sec})\end{array}$ & $\begin{array}{l}323 \pm 124 \\
(168-600)\end{array}$ & $\begin{array}{l}286 \pm 76 \\
(240-480)\end{array}$ & 0.42 \\
\hline Clinical duration (min) & $\begin{array}{l}165 \pm 190 \\
(43-296)\end{array}$ & $\begin{array}{l}258 \pm 86 \\
(116-380)\end{array}$ & 0.03 \\
\hline $\begin{array}{l}\mathrm{T}_{1} \text { on arrival to recovery } \\
\text { room (\% control) }\end{array}$ & $\begin{array}{l}57 \pm 23 \\
(10-83)\end{array}$ & $\begin{array}{l}24 \pm 21 \\
(0-75)\end{array}$ & 0.003 \\
\hline Recovery index* (min) & $\begin{array}{r}63 \pm 5 \\
(58-69)\end{array}$ & $\begin{array}{l}148 \pm 57 \\
(60-216)\end{array}$ & 0.009 \\
\hline
\end{tabular}

Values are mean $\pm S D$. Numbers in parenthesis are ranges. $T_{1}=$ firs twitch after train of four stimulation.

*For recovery index, $n=5$ in Group 1 and $n=6$ in Group 2.

of technical difficulty with neuromuscular monitoring in one case and because of emergency reoperation due to postoperative bleeding in the other.

There were no differences in HR, MAP, PAOP, SVR, $\mathrm{CI}$ and PWI at any time between the two groups (Figure). A decrease of $\mathrm{HR}$ and $\mathrm{CI}$ was observed in both groups ten minutes after intubation compared with preinduction values $(P<0.025)$. A decrease of MAP was also found in both groups just before intubation $(P<$
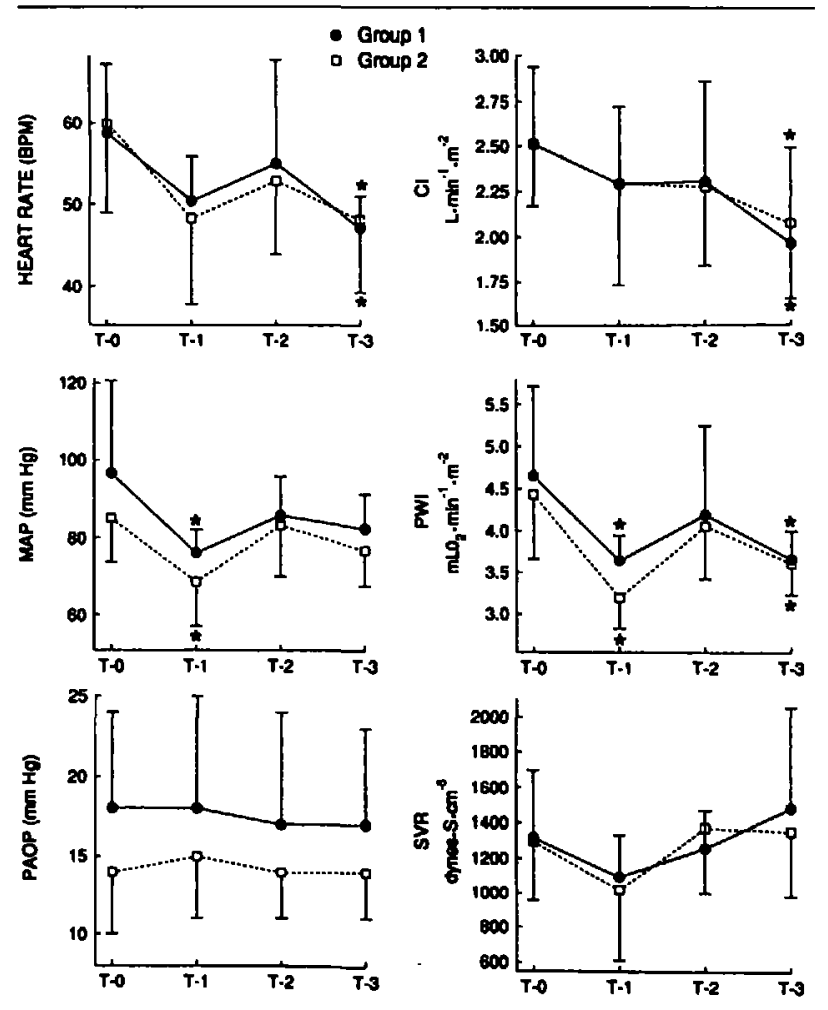

FIGURE Haemodynamic variables of patients given doxacurium $0.05 \mathrm{mg} \cdot \mathrm{kg}^{-1}$ (Group 1) and $0.075 \mathrm{mg} \cdot \mathrm{kg}^{-1}$ (Group 2) during induction of anaesthesia with midazolam and sufentanil. T- $0=$ before induction, $\mathrm{T}-1=$ immediately before intubation, $\mathrm{T}-2=$ one minute after intubation, T-3 $=$ ten minutes after intubation. $\mathrm{MAP}=$ mean arterial pressure. $\mathrm{PAOP}=$ pulmonary artery occluded pressurc. $\mathrm{Cl}=$ cardiac index. $\mathrm{PWI}=$ pressure work index. $\mathrm{SVR}=$ systemic vascular resistance. ${ }^{*} P<0.05$ as compared to values at $T-0$. 
0.025), but MAP returned to pre-induction values one minute after intubation. In both groups, the estimated $\mathrm{MVO}_{2}$ as determined by PWI was lower before intubation $(P<0.02)$ and ten minutes after intubation $(P<$ 0.02 ) than the control values.

Intubating conditions were judged to be excellent in all patients. No muscle rigidity or difficulty in ventilation was observed in any case. No patient developed signs of histamine release such as flushing, wheals or bronchospasm. No patient complained of thumb or arm discomfort related to prolonged nerve stimulation and arm extension. One patient in Group 2 complained of shoulder pain with no evidence of nerve damage. He recovered from this with standard postoperative physiotherapy care.

\section{Discussion}

The main findings of this study are the very slow onset times of doxacurium 0.05 and $0.075 \mathrm{mg} \cdot \mathrm{kg}^{-1}$ in cardiac surgical patients anaesthetized with midazolam and sufentanil, and the markedly prolonged clinical duration of doxacurium during cardiac surgery compared with previously reported values in noncardiac surgery. ${ }^{2-5}$ With both doses of doxacurium during cardiac surgery with hypothermic $\mathrm{CPB}$, the mean onset time of neuromuscular block was greater than six minutes and the clinical duration was increased by 60 to $100 \%$. Like other nondepolarizing muscle relaxants used in similar conditions, doxacurium has a wide range of clinical duration.

A potential benefit in using high doses of a nondepolarizing muscle relaxant for induction of anaesthesia is to decrease onset time of neuromuscular block. Previous investigations in patients of ASA physical status 1 and 2 have shown that the onset time of doxacurium is decreased from six to nearly three minutes when the dose is increased from two to three times $\mathrm{ED}_{95 .}{ }^{2.5}$ In this study, increasing the dose of doxacurium from 0.05 $\mathrm{mg} \cdot \mathrm{kg}^{-1}$ to $0.075 \mathrm{mg} \cdot \mathrm{kg}^{-1}$ did not decrease the time to maximal neuromuscular block. The reason for the absence of dose effect on speed of action in this study may be a type Il error resulting from the small number of patients and the absence of randomization in the dose schedule. However, an onset time of six minutes was also found in another study where doxacurium 0.08 $\mathrm{mg} \cdot \mathrm{kg}^{-1}$ was administered to 30 patients of the same age group undergoing $\mathrm{CABG}$ surgery. ${ }^{8}$ The reason why the onset time is longer in patients with coronary artery disease (CAD) is uncertain. The onset of action of doxacurium is slower in older patients. ${ }^{16}$ Therefore, an age difference between cardiac surgical patients and healthier patients from other studies may partially account for this finding. Another possible explanation is that the speed of action of muscle relaxants depends largely on circulatory factors such as cardiac output, circulation time to muscle and muscle blood flow. ${ }^{17}$ As many patients with CAD have some degree of ventricular dysfunction and are treated with myocardial depressing agents, a slower access of doxacurium to the muscles may decrease its onset time in this population.

The long onset time of doxacurium may limit its use as a muscle relaxant during induction of anaesthesia with an opioid base technique. Ventilatory difficulties due to skeletal muscle rigidity particularly of the chest, abdomen, extremities and jaw are a concern with the use of opioids. ${ }^{18,19}$ None of the patients in this study presented such a problem. This could be attributed to the relatively small amount of opioid (1.5 to $2.5 \mu \mathrm{g} \cdot \mathrm{kg}^{-1}$ of sufentanil) used for induction of anaesthesia. However, similar results were obtained by other investigators while using high doses of fentanyl. ${ }^{8}$

The mean clinical durations of doxacurium 0.05 $\mathrm{mg} \cdot \mathrm{kg}^{-1}$ and $0.075 \mathrm{mg} \cdot \mathrm{kg}^{-1}$ in this study were 165 and $258 \mathrm{~min}$ respectively compared with approximately 100 and $160 \mathrm{~min}$ in noncardiac surgery. ${ }^{2,4,5} \mathrm{~A}$ possible age difference between these patients and those from previous studies may partly explain this finding. ${ }^{16,20}$ A $30 \%$ increase in the clinical duration of doxacurium has been shown when comparing elderly (70-85 years) patients to young adults (18-40 years) undergoing noncardiac surgery. ${ }^{20}$ With a mean age of $58 \mathrm{yr}$, patients in this study belong to a group in between those previously studied. Therefore it is difficult to quantify the age effect, if any, on the results. The magnitude of the increases in clinical duration of doxacurium is probably better explained by the effects of hypothermia and CPB. Both mild intraoperative hypothermia ${ }^{21}$ and moderate hypothermia during $\mathrm{CPB}^{9-11}$ are associated with an increased intensity and duration of neuromuscular block. For example, pancuronium requirements are decreased by $84 \%$ during hypothermic CPB. ${ }^{22}$ The present study was not confined to the time of $\mathrm{CPB}$, but to the whole perioperative period. Therefore comparisons with studies of requirements of other muscle relaxants during CPB alone are impossible. However, as nearly $45 \%$ of the surgical period involved $\mathrm{CPB}$ and as this was followed by two to four hours of mild hypothermia during recovery, it is logical to assume that hypothermia is the common denominator between this study and those conducted during CPB. The mechanisms by which hypothermia enhances or prolongs the effect of nondepolarizing muscle relaxants are not completely understood and may vary from one experimental condition to the other. The direct effects of temperature on the muscle, ${ }^{21}$ increased sensitivity of the neuromuscular junction to muscle relaxants ${ }^{22}$ and pharmacokinetic 
changes ${ }^{23,24}$ may all contribute to the increased duration of action of relaxants during hypothermia. The contribution of each of those factors to the prolonged duration of doxacurium during cardiac surgery has not been determined.

The recovery index of doxacurium could only be determined in a small number of patients, most of them having received repeated doses of doxacurium intraoperatively. It has been shown that repeated doses may increase the recovery indices of nondepolarizing muscle relaxants. ${ }^{25}$ Changes in neuromuscular junction sensitivity may also accompany the core temperature fluctuations over time and modify the recovery pattern of muscle relaxation. ${ }^{20}$ For those reasons the results of this study may not reflect the true recovery index associated with each initial dose of doxacurium in this population. However the wide range of recovery indices observed in this study emphasizes the fact that the spontaneous recovery of doxacurium may be quite long in some cardiac surgical patients.

The haemodynamic stability associated with high doses of doxacurium in the cardiac surgical population is well recognized. ${ }^{6-8}$ Not surprisingly, the haemodynamic responses observed in this study are similar to those from previous reports. The small haemodynamic changes observed in the two groups of patients were not clinically important and were probably the results of the anaesthesia induction with midazolam and sufentanil. The main reason to record the haemodynamic variables was to document factors affecting drug circulation time. The two groups had comparable demographic and haemodynamic characteristics suggesting that access of doxacurium to the muscles was similar in both groups despite the non randomization of patients.

The safety of high doses of doxacurium in patients whose tracheas will be extubated two to six hours after cardiac surgery has not been assessed. However this study provides relevant information regarding the use of doxacurium in those patients. First, the prolonged clinical duration of both doses of relaxant suggests that reversal of neuromuscular block may be necessary in many patients if tracheal extubation is performed within three hours of a four hour procedure. Second, the comparable onset times with both doses and the fact that a single dose of $0.075 \mathrm{mg} \cdot \mathrm{kg}^{-1}$ may induce profound neuromuscular block lasting more than six hours favour the use of the smaller dose $\left(0.05 \mathrm{mg} \cdot \mathrm{kg}^{-1}\right)$ in cardiac surgical patients whose tracheas will be extubated early.

This study shows that the pharmacodynamic variables of high doses of doxacurium in patients undergoing CABG surgery with hypothermic CPB are different from those in healthier patients undergoing noncardiac surgery. The onset time of doxacurium in patients with
CAD is slower. The reason for this is unclear, but may be related to differences in age and circulation time between healthier patients and those with CAD. Finally, the clinical duration of doxacurium is markedly prolonged in cardiac surgical patients. The older age of the cardiac surgical population may be partly responsible for this finding. However the prolonged perioperative period of hypothermia associated with the use of hypothermic CPB is probably the major cause of the prolonged effect of doxacurium observed in this study.

\section{Acknowledgements}

The authors thank Joanne Sweet, RN, Marlene Farrell, RN, Maureen Burns, RN, and Geraldine Wells for their assistance.

\section{References}

I Murray DJ, Mehta MP, Choi WW, et al. The neuromuscular blocking and cardiovascular effects of doxacurium chloride in patients receiving nitrous oxide narcotic anesthesia. Anesthesiology 1988; 69: 472-7.

2 Basta SJ, Savarese JJ, Ali HH, et al. Clinical pharmacology of doxacurium chloride: a new long-acting nondepolarizing muscle relaxant. Anesthesiology 1988; 69: 478-86.

3 Scott RPF, Norman J. Doxacurium chloride: a preliminary clinical trial. Br J Anaesth 1989; 62: 373-7.

4 Katz JA, Fragen RJ, Shanks CA, Dunn K, McNulty B, Rudd $G D$. Dose-reponse relationships of doxacurium chloride in humans during anesthesia with nitrous oxide and fentanyl, enflurane, isoflurane, or halothane. Anesthesiology 1989; 70: 432-6.

5 Lennon RL, Hosking MP, Houck PC, et al. Doxacurium chloride for neuromuscular blockade before tracheal intubation and surgery during nitrous oxide-oxygen-narcoticenflurane anesthesia. Anesth Analg 1989; 68: 255-60.

6 Stoops CM, Curtis CA, Kovach DA, et al. Hemodynamic effects of doxacurium chloride in patients receiving oxygen sufentanil anesthesia for coronary artery bypass grafting or valve replacement. Anesthesiology 1988; 69: 365-70.

7 Emmott RS, Bracey BJ, Goldhill DR, Yate PM, Flynn PJ. Cardiovascular effects of doxacurium, pancuronium and vecuronium in anaesthetized patients presenting for coronary artery bypass surgery. Br J Anaesth 1990; 65: 480-6.

8 Searle NR, Sahab P, Blain R, et al. Hemodynamic and pharmacodynamic comparison of doxacurium and highdose vecuronium during coronary artery bypass surgery: a cost-benefit study. J Cardiothorac Vasc Anesth 1994; 8: 490-4.

9 Denny NM, Kneeshaw JD. Vecuronium and atracurium infusions during hypothermic cardiopulmonary bypass. Anacsthesia 1986; 41: 919-22.

10 Buzello W, Schluermann D, Pollmaecher T, Spillner G. 
Unequal effects of cardiopulmonary bypass-induced hypothermia on neuromuscular blockade from constant infusion of alcuronium, d-tubocurarine, pancuronium, and vecuronium. Anesthesiology 1987; 66: 842-6.

11 Futter ME, Whalley DG, Wynands JE, Bevan DR. Pancuronium requirements during hypothermic cardiopulmonary bypass in man. Anaesth Intensive Care 1983; 11 : 216-9.

12 Cheng DCH, Karski J, Peniston C, et al. A prospective randomized, controlled clinical trial of early versus conventional tracheal extubation following coronary artery bypass graft (CABG) surgery: postoperative complications and hospital discharge. Can J Anaesth 1994; 41 : A49.

13 Higgins TL. Pro: early endotracheal extubation is preferable to late extubation in patients following coronary artery surgery. J Cardiothorac Vasc Anesth 1992; 6: 488-93.

14 Swenson JD, Hullander RM, Wingler $K$, Leivers $D$. Early extubation after cardiac surgery using combined intrathecal sufentanil and morphine. J Cardiothorac Vasc Anesth 1994; 8: 509-14.

15 Rooke GA, Feigl EO. Work as a correlate of canine left ventricular oxygen consumption, and the problem of catecholamine oxygen wasting. Circ Res 1982; 50: 273-86.

16 Dresner DL, Basta SJ, Ali HH, et al. Pharmacokinetics and pharmacodynamics of doxacurium in young and elderly patients during isoflurane anesthesia. Anesth Analg 1990; 71: 498-502.

17 Donati $F$. Onset of actions of relaxants. Can J Anaesth 1988; 35: S52-8.

18 Goldberg M, Ishak S, Garcia C, McKenna J. Postoperative rigidity following sufentanil administration. Anesthesiology 1985; 63: 199-201.

19 Rathmell JP, Brooker RF, Prielipp RC, Butterworth JF, Gravlee GP. Hemodynamic and pharmacodynamic comparison of doxacurium and pipecuronium with pancuronium during induction of cardiac anesthesia: does the benefit justify the cost? Anesth Analg 1993; 76: 513-9.

20 Koscielniak-Nielsen ZJ, Law-Min JC, Donati F, Bevan $D R$, Clement $P$, Wise $R$. Dose-response relations of doxacurium and its reversal with neostigmine in young adults and healthy elderly patients. Anesth Analg 1992; 74: 845-50.

21 Heier T, Caldwell JE, Sessler DI, Miller RD. The effect of local surface and central cooling on adductor pollicis twitch tension during nitrous oxide/isoflurane and nitrous oxide/fentanyl anesthesia in humans. Anesthesiology 1990; 72: 807-11.

22 Miller RD, Agoston S, van der Pol F, Booij LHDJ, Crul $J F$, Ham J. Hypothermia and the pharmacokinetics and pharmacodynamics of pancuronium in the cat. J Pharmacol Exp Ther 1978; 207: 532-8.

23 Heier T, Caldwell JE, Eriksson LI, Sessler DI, Miller RD.
The effect of hypothermia on adductor pollicis twitch tension during continuous infusion of vecuronium in isoflurane-anesthetized humans. Anesth Analg 1994; 78: 312-7.

24 Cheng DCH, Asokumar B, Chung F, et al. Pharmacokinetics of doxacurium chloride during normothermic and hypothermic cardiopulmonary bypass sugery. Can J Anaesth 1993; 40: A33.

25 Fisher DM, Rosen JI. A pharmacokinetic explanation for increasing recovery time following larger or repeated doses of nondepolarizing muscle relaxants. Anesthesiology 1986; 65: 286-91. 